\title{
Effects of Ethanol on Isolated Hepatocytes : Alteration in Cell Surface and Intracellular ATP
}

Nelson Simanungkalit

\begin{abstract}
Abstrak
Ethanol merupakan salah satu toxin yang sangat berbahaya terhadap hati. Walau studi tentang keracunan ethanol telah banyak dilakukan, namun mekanisme keracunannya masih mengundang banyak pertanyaan. Tujuan penelitian ini ialah pertama menunjukkan pengaruh ethanol terhadap permukaan sel hati dan kedua terhadap konsentrasi ATP intrasel. Pemaparan ethanol terhadap sel hati rikus yang diisolasi menimbulkan terbentuknya penonjolan di permukaannya, sedangkan konsentrasi ATP intrasel menurun secara bermakna $(p<0,05)$.
\end{abstract}

\begin{abstract}
One of the most serious hepatotocix agents to the liver is ethanol. Although its toxicity has been investigated, the toxic mechanism itself remains controversial. The aims of the present work are to investigate the effect of ethanol on the surface of freshly isolated hepatocytes after incubation with ethanol, and its influence on cytosolic ATP-concentration. Incubation with ethanol led to the specific formation of reversible blebs on the surface of hepatocytes and a significant decrease $(p<0,05)$ of cyrosolic ATP-concentration.
\end{abstract}

Keywords : hepatology, erhanol toxicity, bleb formation

Liver is the main organ which metabolizes ethanol. Although the liver is at the beginning resistant against the influence of ethanol, the continous uptake of ethanol in high doses can damage liver cell producing a pathological state such as "cirrhosis". Many studies on ethanol-toxicity has been carried out, however its mechanism is still not clear. The present paper will describe two studies about the influence of ethanol on hepatocytes. Firstly, its influence to the cell surface as pictured by scanning electron microscopy and secondly its influence on the intracellular ATP concentration.

\section{MATERIALS AND METHODS}

Sprague-Dawley rats (ca. $220 \mathrm{~g}$ ) were obtained from Savo, medizinische Versuchstierzuchten $\mathrm{GmbH}$, Kisslegg/Allgaeu, Germany.

Isolated hepatocytes were prepared by collagenase perfusion. ${ }^{.}$Cell viability, as judged by trypan blue exclusion, ${ }^{2}$ was between 85 to $95 \%$ for all preparations. Following isolation, a suspension of hepatocytes containing $1-1.5$ million cells/ml was transfered to plastic vials ( $10 \mathrm{ml}$ ). Ham's F- 12 medium and ethanol of different concentrations $(0.3-2.6 \mathrm{~mol} / \mathrm{l})$ were added, so that the final volume was $1.0 \mathrm{ml}$ in all experiments. The contents were mixed gently, and the vials were kept in a waterbath at temperature of $25^{\circ} \mathrm{C}$ for $30 \mathrm{~min}$.

\section{Scanning electron microscopy}

1 to 1.5 million hepatocytes for electron microscopic scanning were fixed in $1 \%$ glutaraldehyde in $0.1 \mathrm{~mol}$ cocodylate-buffer, washed washing (2 times) with cocodylate-buffer for $15 \mathrm{~min}$ each, followed by the fixation with $0.5 \%$ Os (VIII)-oxide for $1 \mathrm{~h}$. Dehydration was carried out using 50-, 70 - and $100 \%$ alcohol for $5 \mathrm{~min}$ each. The air dried samples were then put on "leit-Tabs" (Plano), evaporated with gold-palladium (Sputter coater, Bio-Rad) and examined with JSM, U3 - scanning electron microscope. 


\section{Determination of the ATP content of hepatocytes}

The ATP content of isolated hepatocytes was measured $^{3,4}$ using Auto-CliniLuminat (LB 952T/16) from Berthold, Wildbad. A $100 \mu \mathrm{l}$ aliquot was taken from the cell suspension $(1 \mathrm{ml})$ for the viability determination. The remaining vials content $900 \mu \mathrm{l}$ was put in crushed ice for 5 minutes to enhance the sedimention of the cells. To remove the supernatant, the cell suspension was washed 3 times each with $1 \mathrm{ml}$ physiological saline. After centrifugation for $5 \min (200 \mathrm{xg})$ at $4^{\circ} \mathrm{C}$, the supernatant was carefully pipetted out and $900 \mu 1$ TCA (5\%) was added to the cells. The cell suspension was then homogenized using a Branson Sonifier. After centrifugation at $3000 \mathrm{x} \mathrm{g}$ for $15 \mathrm{~min}$ at $4^{\circ} \mathrm{C}, 50 \mu \mathrm{l}$ of supernatant was diluted $1: 41$ ( $\mathrm{vol} / \mathrm{vol})$ with physiological saline.

The measurement was done 5 seconds after $60 \mu \mathrm{l}$ of the diluted solution was mixed with ATP-reagent.
Diluted $5 \mathrm{mmol} / \mathrm{l}$ ATP- $\mathrm{Na}_{2} \mathrm{H}_{2} \quad .3 \mathrm{H}_{2} \mathrm{O}$ was used as ATP-standard. During the measurement, the sample were stored at cold temperature.

\section{RESULTS}

Freshly isolated hepatocytes were examined with a scanning electron microscope. The shape of a normal hepatocyte is mostly round or oval with a rough surface (Figure 1).

Freshly isolated hepatocytes, exposed to ethanol of a dose ranging from 0.3 . to $2.6 \mathrm{~mol} / \mathrm{l}$, produced blebs on the cell surfaces. Observation by scanning electron microscopy showed blebs of various sizes on the cell surface, with large sized blebs resembling cucumbers (Figure 2).

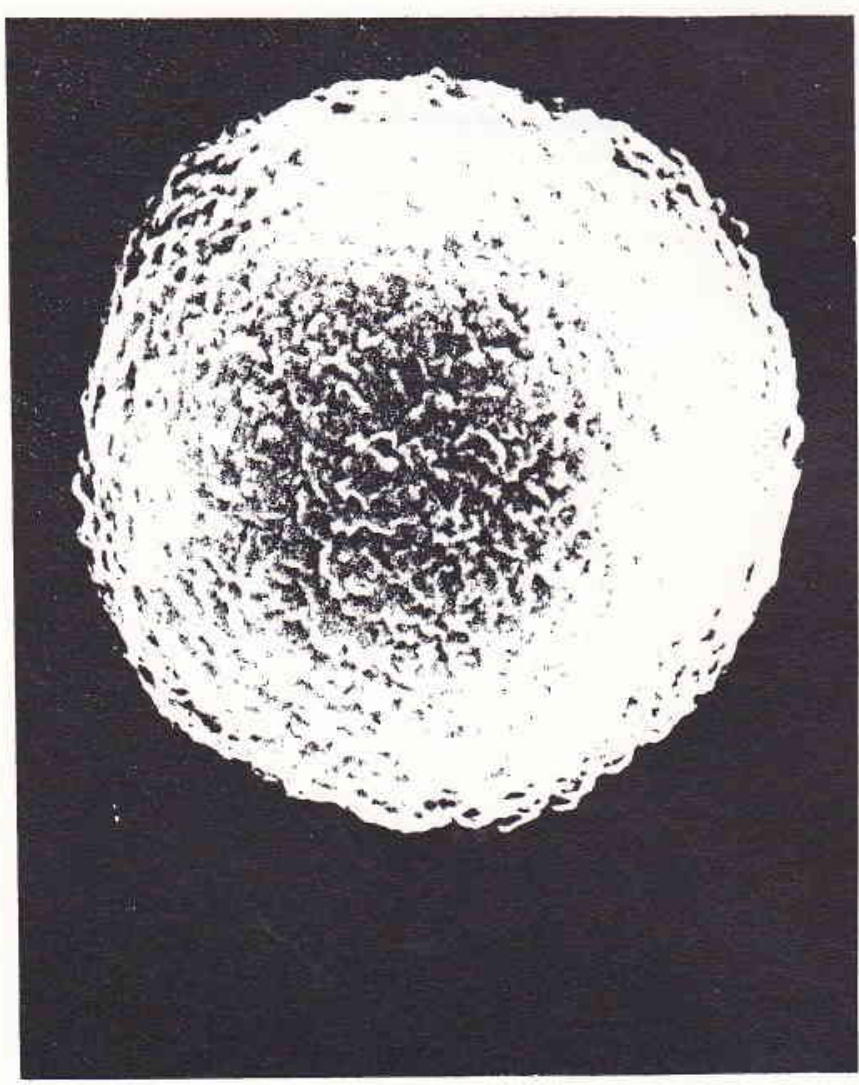

Figure I. Scanning electron micrograph of a normal, freshly isolated hepatocyte

Magnifications : 3000

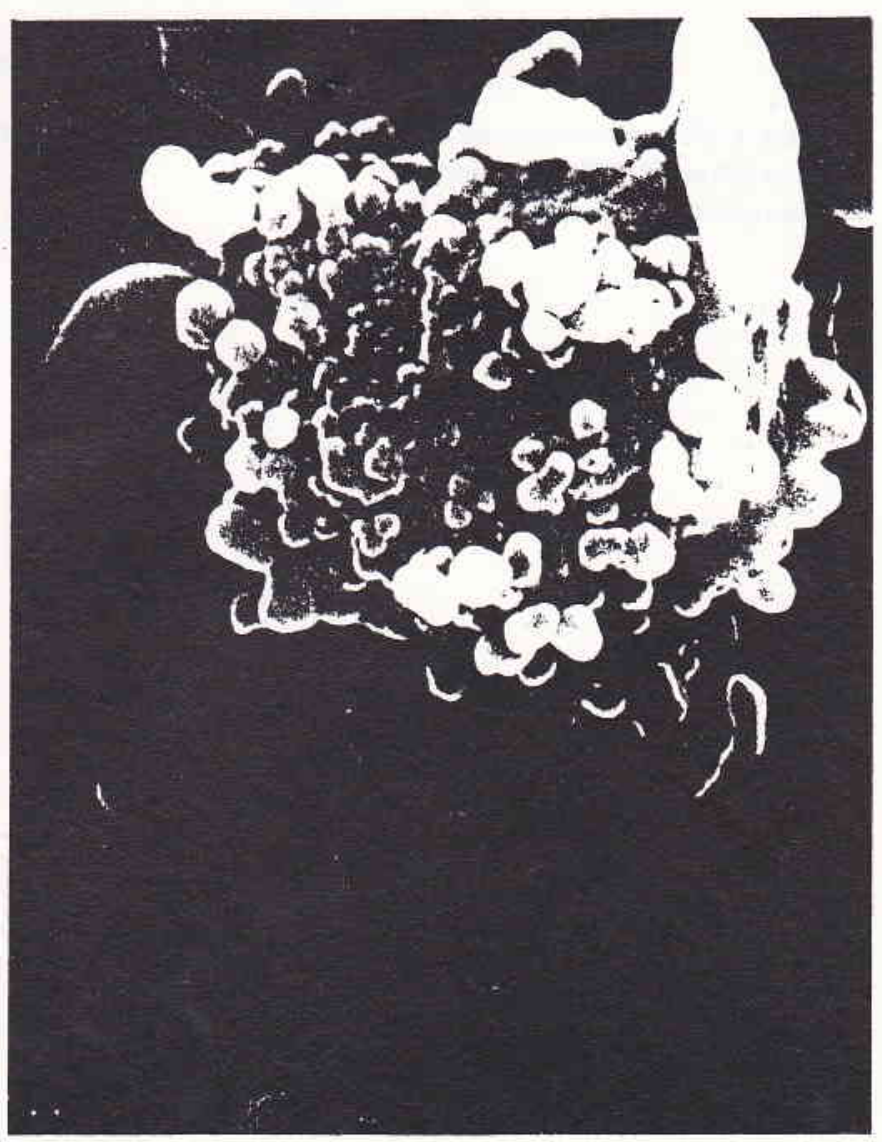

Figure 2. Scanning electron micrograph of a freshly isolated hepatocyte in the presence of 0.65 mol ethannl/ for $30 \mathrm{~min}$ at $25^{\circ} \mathrm{C}$. Magnifications: $3000 x$ 
As shown in Figure 3 , the blebbing caused by ethanol were dose dependent. At concentration 2.6 $\mathrm{mol} / 1$ the formed blebs reached $93.3 \pm 1,2 \%$. The $\mathrm{BD}_{50}$-value, the concentration of ethanol, where $50 \%$ of the hepatocytes formed blebs is $0.35 \mathrm{~mol} / \mathrm{l}$.

Measurement of intracellular ATP of normal, freshly isolated hepatocytes showed a concentration of
$22.3 \pm 2.2 \mathrm{nmol} \mathrm{ATP} / \mathrm{mg}$ cell protein (Figure 4 ). If freshly isolated hepatocytes were exposed to 0.65 $\mathrm{mol} / \mathrm{l}$ ethanol for $30 \mathrm{~min}$ at $25^{\circ} \mathrm{C}$, the ATP concentration decreased significantly $(\mathrm{p}<0.05, \mathrm{n}=3)$ to $15 \pm 1,2$ nmol ATP/mg cell protein.

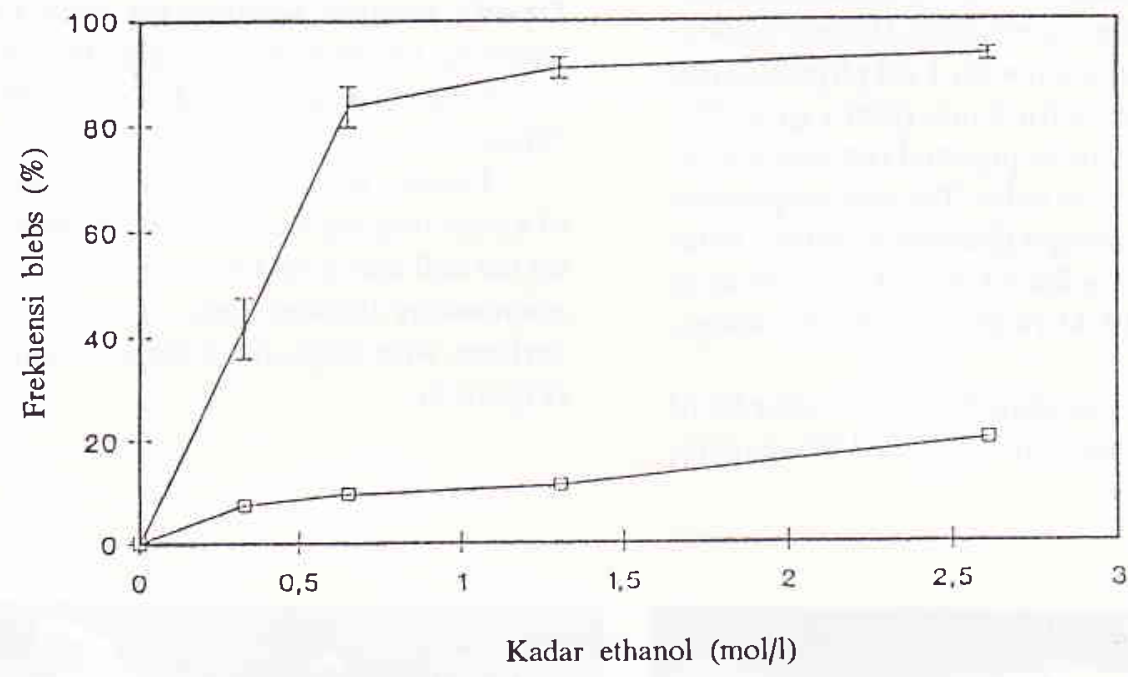

Figure 3. Blebs formation and cell death after exposure of hepatocytes to various concentration of elhanol (0.3 to $\left.2.6 \mathrm{~mol} / \mathrm{l}, 25^{\circ} \mathrm{C}, 30 \mathrm{~min}\right)$.

Data represent means $\pm S D(n=5)$.

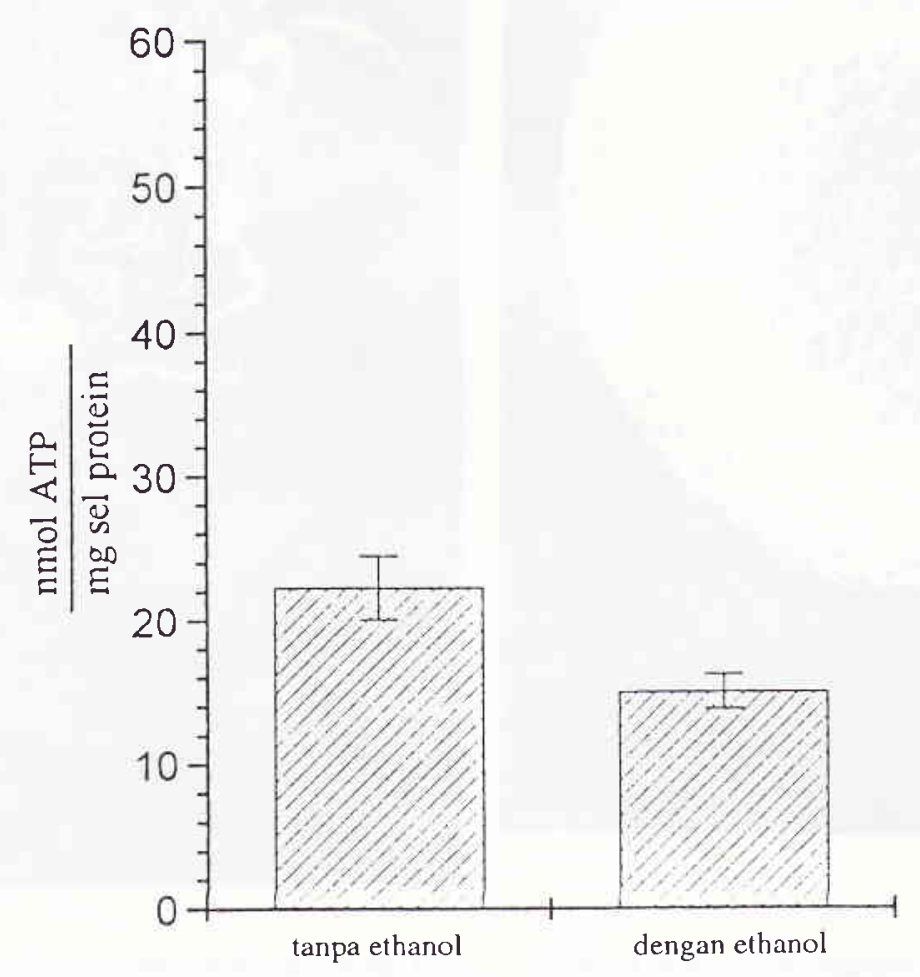

Figure 4. ATP depletion afier exposure to $0.65 \mathrm{~mol} / \mathrm{l}$ ethanol $\left(25^{\circ} \mathrm{C}, 30 \mathrm{~min}\right)$.

Data represent means $\pm S D(n=3)$ 


\section{DISCUSSION}

Cell surface blebbing is an early indication of hypoxic and oxic injury to hepatocytes. ${ }^{2,5,6,7}$ Ethanol caused blebbing on the surface of freshly isolated hepatocytes. ${ }^{8}$ In comparison to blebs caused by phalloidin, ${ }^{9,10}$ dicoumarol plus manadione ${ }^{6}$ and extracellular ATP, ${ }^{11}$ the blebs caused by ethanol were different. Scanning electron micrograph showed large sized blebs resembling to cucumbers. It seemed that the blebs are typical depending on the hepatotoxic agent.

Another important observation was the reversibility of the blebs. The blebs dissapeared within 30 minutes.

Ethanol interact with biological membranes. ${ }^{12}$ This interaction affects physical and chemical properties of membranes and may cause inhibition of transmembrane signaling processes.

Other authors considered that acetaldehyde an intermediate product during ethanol metabolism, and alteration of NAD/NADH ratio were responsible for the cell damage. ${ }^{13,14,15,16}$ Several authors suggested that the blebs formation was associated with the rise in cytosolic $\mathrm{Ca}^{2+} \cdot 6,7,17$ Since exposure of freshly isolated hepatocytes to ethanol caused blebbing it was suggested that ethanol may also cause a rise in cytosolic $\mathrm{Ca}^{2+}$. In our experiments cytosolic $\mathrm{Ca}^{2+}$ was not measured, but there was an evidence of an increase of cytosolic $\mathrm{Ca}^{2+}$ due to ethanol toxicity. Further, it was reported that the rise was temporary. ${ }^{18}$ Observations in this study showed that the blebs were reversible. There seems to be a relationship between the blebs formation and the rise in cytosolic $\mathrm{Ca}^{2+}$.

As the concentration of the cytosolic $\mathrm{Ca}^{2+}$ was increased, ATP consumption can be expected to increase too since it is known that transportation of $2 \mathrm{~mol}$ $\mathrm{Ca}^{2+}$ from intra to extracell consumes 1 mol of ATP. The results of this study confirmed this expectation; the ATP concentration decreased significantly $(\mathrm{p}<$ $0.05, \mathrm{n}=3$ ) from $22.3 \pm 2.2 \mathrm{nmol} \mathrm{ATP} / \mathrm{mg}$ cell protein. Whether this ATP depletion was only caused of $\mathrm{Ca}^{2+}$ ATP-ase-Pump or not still need further investigation, since ethanol inhibits glycolysis. ${ }^{19}$

\section{CONCLUSIONS}

In vitro exposure of freshly isolated hepatocytes exposed to ethanol cause blebbing at the surface of the hepatocytes. The produced blebs were reversible and some of them had a typical shape, resembling a cucumber. Exposure to $0.65 \mathrm{~mol}$ ethanol/l for $30 \mathrm{~min}$ caused a significant decrease $(p<0,05)$ of intracellular ATP.

\section{Aknowledgement}

Aknowledgement are due to the Bureau for Assessment and Application of Technology of Republic of Indonesia as well as Prof. Dr.G.S.Rao for giving me access to do research at the Institut der Klinische Biochemie der Universitaet Bonn, Germany. I am also grateful to Mr. J. Bedorf at the Institut fur experimentalle Pathologie der Universitaet Bonn for his help in taking photographs from scanning electron microscope.

\section{REFERENCES}

1. Eckel J, Rao GS, Rao ML, Breuer H. Uptake of L-triiodothyronine by isolated rat liver cells. Biochem J 1979; 182:473-91.

2. Rao GS, Lemoch H, Kessler H, Damm I, Eiermann V, Koll S, Zarbock J, Usadel KH. Prevention of Phalloidin-induced Lesions on Isolated Rat Hepatocytes by Novel Synthetic Analogues of Somatostatin. Klin Wochenschr 1986; 64.

3. De Luca M, Mc Elroy WD. In Methods of Enzymology (Ed: SP Colowick, NO Kaplan) 1978; 57:3.

4. De Luca M. Firefly Luciferase. Advances Enzymol 1969; 44:37-68.

5. Lemasters JJ, Ji S, Thurman RG. Centrilobular injury following hypoxia in isolated, perfused rat liver, Science 1981; 213:661-3.

6. Jewell SA, Bellomo G, Thor H, Orrenius S. Bleb Formation during Drug Metabolism is Caused by Disturbances in Thiol and Calcium Ion Homeostasis. Science 1982; 217:1257-9.

7. Lemaster JJ, Stemkowski CJ, Ji S, Thurman RGJ. Cell Biol 1983;97:778-86.

8. Rao GS, Lemoch H, Usadel KH. Behandlung mit Somatostatin schützt die Rattenleberzelle gegen Läsionen durch Phalloidin, Äthanol und Dimethylsulfoxid. V. Freiburger Kolloqium, ATTEMPTO Verlag Tübingen GmbH 1982.

9. Weiss E, Sterz I, Frimmer M, Kroker R. Electron Microscopy of Isolated Rat Hepatocytes before and after Treatment with Phalloidin. Beitr Path Bd 1973;150:345.

10. Frimmer M. What we have learned from Phalloidin. Toxycology Letters 1987;35:169-82.

11. Nicotera P, Hartzell P, Baldi C, Svenson S, Bellomo G, Orrenius S. Cystamine Induces Toxicity in Hepatocytes through the Elevation of Cytosolic $\mathrm{Ca}^{2+}$ and the Stimulation of a Nonlysosomal Proteolytic System. J Biol Chem 1986; 261:31(5).

12. Taraschi TE, Rubin E. Biology of Disease Effects of Ethanol on the Chemical and Structural Properties of Biologic Membranes. Laboratory Investigation 1985; 51 (2):120 Lab Invest $41: 393$.

13. Sorrell MF, Tuma DJ. Effect of alcohol on hepatic metabolism: selected aspects. Clin Sci 1979; 57:481-9.

14. Sorrell MF, Tuma DJ. The Functional Implications of Acetaldehyde Binding to Cell Constituents. Ann New York Acad Sci 1987; Vol 492. 
15. Lieber C. Alcohol and liver: 1984 update. Hepatology 1984; 1234-60.

16. Mezey E. Metabolic effects of alcohol. Fed Proc 1985; 44:134-8.

17. Thor H, Hartzell P, Orrenius S. J Biol Chem 1985; 259: 6612-5.
18. Hoek JB, Thomas AP, Rubin R, Rubin E. Ethanol-induced Mobilization of Calcium by Activation of Phosphoinositide specific Phospholipase C in Intact Hepatocytes. J Biol Chem 1987; $262: 2$.

19. Greiling H, Gressner AM. Lehrbuch der klinischen Chemie und Pathobiochemie. 2 Auflage, Schattauer Verlag, 1989. 